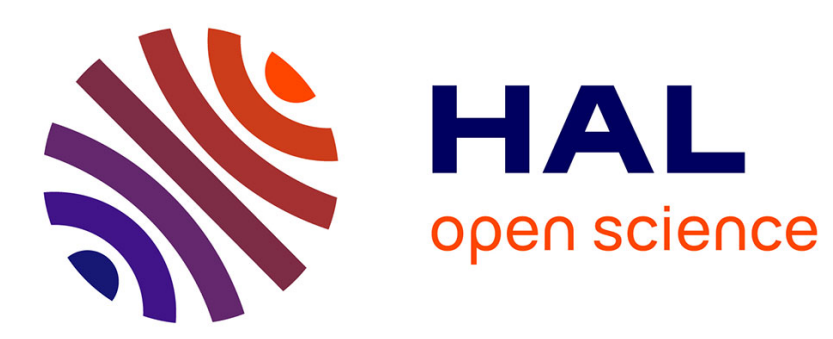

\title{
Wage-led demand as a rebalancing strategy for economic growth in China
}

\author{
Bruno Jetin, Luis Reyes-Ortiz
}

\section{To cite this version:}

Bruno Jetin, Luis Reyes-Ortiz. Wage-led demand as a rebalancing strategy for economic growth in China. Envisioning the Economy of the Future and the Future of Political Economy, AFEP-IIPPE International Conference, Jul 2019, Lille, France. pp.341-366, 10.1080/01603477.2020.1774392 . halshs03193667

\section{HAL Id: halshs-03193667 https://shs.hal.science/halshs-03193667}

Submitted on 9 Apr 2021

HAL is a multi-disciplinary open access archive for the deposit and dissemination of scientific research documents, whether they are published or not. The documents may come from teaching and research institutions in France or abroad, or from public or private research centers.
L'archive ouverte pluridisciplinaire HAL, est destinée au dépôt et à la diffusion de documents scientifiques de niveau recherche, publiés ou non, émanant des établissements d'enseignement et de recherche français ou étrangers, des laboratoires publics ou privés. 


\title{
Wage-led demand as a rebalancing strategy for economic growth in China
}

Paper presented at International AFEP-IIPPE Conference, Envisioning the Economy of the Future and the Future of Political Economy, 3 to 5 July 2019, Lille, France.

Final draft published in:

B. Jetin and Luis Reyes (2020). "Wage-led demand as a rebalancing strategy for economic growth in China". Journal of Post Keynesian Economics. 43, (3), p 341-366. DOI: $\underline{10.1080 / 01603477.2020 .1774392}$

Bruno Jetin

Institute of Asian Studies, University of Brunei Darussalam,Jalan Tungku Link, BE1410, Gadong, Brunei Darussalam

E-mail address: bruno.jetin@ubd.edu.bn

Luis Reyes

Kedge Business School, Domaine de Luminy, Marseille, France.

E-mail: $\underline{\text { luis.reyes@kedgebs.com }}$

\begin{abstract}
Rebalancing growth in favor of domestic consumption has been an objective of Chinese policy makers for over two decades. However, until recently little progress has been achieved. This article argues that the nature of the demand regime is a major reason for the limited rebalancing operated thus far. Until the great recession (2008-09), Chinese growth was profit-led, which means that an increase in the profit share of income had a positive effect on investment and net exports that exceeded the negative effect on consumption. We show that after the great recession, China's demand regime turned wage-led, which means that an increase in the wage share results in a positive effect on households' consumption which exceeds the negative effect on investment and net exports. The conclusion is that a pro-labor policy may now contribute to rebalance China's growth and make it less dependent on exports, overinvestment and carbon-intensive industries.
\end{abstract}

Keywords: E01;E12;E25;E61;C32

\section{Introduction}

China's growth is famous for its extraordinary performance during the last two decades with growth peaking at an average of 10 percent for the period 1997 to 2010 and GDP per capita more than tripled. Exports growth played an important role especially after China joined the World Trade Organization in 2001. The Chinese economy was integrated into global value chains and 
became an important final assembler of manufactured goods exported all over the world. Net exports surplus peaked at $8.6 \%$ of GDP in 2007 and China became the largest global exporter in 2008. These remarkable achievements led many observers to consider this country as a remarkable case study of export-led growth. Nonetheless, a growth accounting exercise shows that domestic investment has been the main driver of growth, in particular after the great recession (2008-09) when the government launched in 2011 a stimulus plan that boost investment up to $48 \%$ of GDP (see Figure 1).

Figure 1: Structure of China's demand, 1998-2017

Net exports played an additional but secondary role until the global recession and declined to less than 3\% of GDP since then. As growth was decelerating and reaching a "new normal" pattern, foreign trade was shifting and turning into a "normal system" more closely linked to the local economy (Lemoine \& Unal, 2017). At the opposite, households' consumption declined to historical low levels when China was comparable to other countries. It reached a minimum of 35.6\% in 2010 and recovered gradually from then onwards. This situation highlights the need to rebalance Chinese growth. Investment cannot stay at such a high level indefinitely because it has led to overcapacity in construction and heavy industries, to a speculative bubble in real estate (Zhao et. al., 2017) and to excessive corporate debt ${ }^{1}$ which turned into bad loans for banks. Households' consumption has been crippled by a declining labor share compounded by rising income inequalities and the need to accumulate precautionary savings in order to cope with education, health and accommodation expenses (Zhang, 2016).

Figure 2: Labour income and household consumption in China, 1978-2016

The strong trade deficit that many countries have registered with respect to China implies that a new bout of Chinese exports would not be tolerated, as it is shown by the recent trade war with the United States. A lower rate of investment and a commensurate increase in the rate of households' consumption is therefore necessary to rebalance growth. This does not mean a purely internal readjustment of the components of growth. Rebalancing growth implies both an external and an internal process. For instance, an appreciation of the Yuan is likely to worsen China's competitiveness, reduce manufacturing exports and the incentive to invest in export industries (Blanchard \& Giavazzi, 2006, pp. 17-18). The negative impact on growth and investment has to be compensated by an increase in households' consumption. The latter can only come from a mix of lower precautionary savings, a higher labor income share, a decline in income and wealth inequality and a rise in service jobs to offset the reduction in manufacturing employment.

In short, rebalancing the Chinese economy is not a short-term adjustment but implies a comprehensive change that alters the structure of the economy both on the supply and the demand side (Zhang, 2016). This article does not deal with all the aspects of this structural change but focuses rather on the demand side. To this effect, we rely on the Post-Keynesian theory which is primarily concerned with the relations between income distribution and demand regimes. Classical political economy had concluded that demand is profit-led while Post-Keynesian theory adds the possibility that demand can also be wage-led (Setterfield, 2016). "An economy is in a profit-led

\footnotetext{
${ }^{1}$ At the end of 2017, Non-financial Corporate debt (138\% of GDP) is high, and the situation is even worse when the share of LGFV credit to corporates is included (160\%). This figure is much higher than comparable data in the USA (78\%), Japan (103\%), euro area (101\%), South Korea (98\%), Malaysia (67.2\%) or Thailand (48\%). For Chinese non-financial private companies, total debt stands at 208\%, much above all other countries. Source: BIS, Total Credit Statistics, accessed 12 July 2018.
} 
demand regime when an increase in the profit share leads to an increase in the sum of the components of aggregate demand" (households' consumption, government consumption, private investment, and net exports) (Lavoie \& Stockhammer, 2013, pp. 21-22). "An economy is in a wage-led demand regime when an increase in the wage share leads to an increase in the sum of the components of aggregate demands" (Lavoie and Stockhammer, op cit, pp. 21-22). Because government consumption is exogenous, only the effect of a change in income distribution on private consumption and investment is considered in a domestic economy. In an open economy, the additional effect on net exports is added. An increase in the wage share is expected to lead to an increase in households' consumption because the propensity to consume out of wages is higher than the propensity to consume out of profits. It is expected to have a negative effect on investment because the profit share declines. It will have a negative effect on net exports due to the rise in unit labor costs and a consequent decline in price competitiveness. Whether the positive effect on households' consumption is higher than the negative effect on investment and net exports is a purely empirical issue. The interest of the Post-Keynesian theory is precisely to determine if an increase in the wage share can lead to rebalancing China's economy if this economy is in a wageled demand regime. The question is legitimate because the wage share, which has remained above $50 \%$ of GDP since 1978, declined from a 53.4\% peak in 1995 to a $43.5 \%$ trough in 2007 at the eve of the great recession. It recovered slightly from that year and reached $47.5 \%$ in $2016^{2}$. It remains to be determined if this relatively recent increase in the wage share had a positive effect on aggregate demand. To this end we present the details of the model in section 2 and the results of the econometric investigation in section 3 that are in turn discussed in section 4 . Section 5 draws the conclusions regarding the rebalancing of China's growth.

\section{The model}

Following Stockhammer, Onaran and Ederer (2008) as well as Jetin and Kurt (2016), both in turn inspired by (Bhaduri \& Marglin, 1990), we define aggregate demand using a general formula from which we can derive the effect of a change in the functional distribution of income on output. Thus,

$A D=C(Y, \Omega)+I(Y, \Omega, z I)+G(Y, z G)+N X(Y, \Omega, z N X)$

Where $A D$ is aggregate demand, $C, I, G$ and $N X$ are the components of $G D P$ by the demand approach (i.e. consumption, private investment public expenditure and net exports). $\Omega$ is the labor share and the vectors $z_{I}, z_{G}$ and $z_{N X}$ represent all other determinants of investment, public expenditure and net exports, respectively.

From the outset, we recognize (and later on verify empirically) that the marginal propensity to consume out of wages exceeds the marginal propensity to consume out of profits, which means that a given change in wage income is likely to bring about larger changes in overall demand that an equivalent change in the same direction in profits. Therefore, a reduction in either the average wage per worker and/or in the number of employees (controlling for productivity) is likely to bring about a fall in overall domestic demand. This negative effect, however, can be compensated if foreign demand for domestic products increases enough due to the gain in competitiveness

\footnotetext{
${ }^{2}$ The labor share is calculated as compensation of employees divided by GDP. Source: Authors' calculations with data from the National Bureau of Statistics of China. The detail is provided in appendix.
} 
achieved via a reduction in domestic prices, in turn brought about by a reduction of workers' income. By assuming that the evolution of unit labor costs follows closely that of the labor share, which determines domestic prices, we are able to analyze the effect of a change in the functional distribution of income on demand components.

Consumption depends on income, where we differentiate consumption demand stemming from wages $(W)$ and from profits $(\Pi)$. Investment is determined by an accelerator effect (the relationship between output and investment), profits and the real interest rate $(r)$. Public expenditure is assumed to be independent of any of the series described in the model ${ }^{3}$. Exports are determined by foreign demand $\left(M_{W}\right)$ and relative export prices (a proxy for the exchange rate). Imports are a function of domestic demand and relative import prices (i.e. the ratio of domestic prices to import prices).

By differentiating the components of equation (1) with respect to $Y$, by denoting the partial derivative of each of its components ( say $\theta$ ) with respect to domestic demand as $\partial \theta / \partial Y$, we have that $\partial C / \partial Y+\partial I / \partial Y-\partial M / \partial Y$ denotes the effect of the components of domestic demand on the latter. In line with Onaran and Galanis (2012) and Molero-Simaro (2015), although for a different time span, we find that this global effect is positive.

Dividing the partial derivatives just described by the average ratio of the series involved we are able to obtain elasticities which, economically speaking, are more straightforward to interpret. However, an additional step is necessary before getting to these. By estimating the equations belonging to the right-hand side of equation (1), as well as functions for $P$ and $P_{X}$, we are able to compute the partial derivatives of a change in the corresponding variables given a change in wages (alternatively, profits). Once this has been done, we can simply divide this figure by the ratio of the series involved and we can obtain the desired number.

For instance, in order to compute the elasticity of investment with respect to wages, we first estimate the effect of wages on investment (i.e. $\partial I / \partial W$ ) and then divide this number by the ratio $I / W$. The partial derivatives can be obtained from a standard error correction mechanism, as the sum of the coefficients linking changes in wages and its lags with changes in investment. Naturally, the same applies to all the other series affected by wages and/or profits.

Under this theoretical framework, we may define $h_{1}=\partial C / \partial Y+\partial I / \partial Y+\partial N X / \partial Y$ (alternatively $e_{C Y}$, $e_{I Y}$ and $-e_{M Y}$, where all series involved are in logs), and $h_{2}=\partial C / \partial \Omega+\partial I / \partial \Omega+\partial N X / \partial \Omega$, so that the change in aggregate demand given a change in the labor share can be obtained as $d Y^{*} / d \Omega=h_{2} /(1-$ $\left.h_{1}\right)$. These results are more explicitly detailed in the next section. In a nutshell, this effect is the product of the multiplier, defined as $1 /\left(1-h_{1}\right)$, and the sum of the marginal effects of the components of aggregate demand with respect to the labor share. When the sign of the latter (which is determined by $h_{2}$ ) is negative, the economy under analysis is said to be profit-led. Naturally, if the corresponding sign is positive the economy is wage-led. Our empirical results shown in the next section are consistent with this last hypothesis.

\footnotetext{
${ }^{3}$ Although this may be considered a strong assumption, it is common practice in the empirical literature. Moreover, finding the determinants of public expenditure is controversial at best, let alone complicated in a country like China.
} 


\section{Results}

Six standard equations constitute the core of our empirical analysis of the demand regime in China. The figures in tables 2-7 (in log-differences) exhibit the series used in our analysis, in the same order of appearance in the text.

The estimates of equations 2-13 presented are for the long- and short-term specifications for consumption, private investment, exports, imports, domestic prices and export prices.

\section{Consumption}

The long-term specification for consumption (eq. 2) is a log-function of income from workers ( $W$ ) and income from capitalists $(\Pi)$. The adjustment between the dependent variable and its postulated regressands is quite good.

This estimation includes a structural change dummy ${ }^{4}$, which equals 1 from 1995 onwards, and 0 otherwise. This exogenous variable is useful to account for the strong decline in personal consumption that took place since the official take-off of the Chinese economy, which started in the mid-nineties and reflects the decline in the labor share documented in Molero-Simaro (2015). As will be discussed in detail below, our results suggest that the beginning of the profit-led regime started in this period and ended with the global financial crisis, when the wage-led regime replaced the profit-led one. Since the variables in all the specifications enter in logs, the parameters $c^{L T} 1$ and $c^{L T_{2}}$, as well as all the other estimated long-term parameters, are straightforwardly interpreted as elasticities. Thus, a $1 \%$ increase in real wages / profits translates into a $0.49 \% / 0.44 \%$ increase in consumption. The autonomous level of consumption is the exponential of $c^{L T} T_{0}=\exp (0.32)=1.38$ billion of 2010 yuan.

The re-parameterized short-term version of that specification is equation 3, which is in differences and includes lags of all determinants (including the dependent variable) as well as the cointegration vector (i.e. the error term of eq. 2 , a stationary series ${ }^{5}$ ), whose coefficient lies between -1 and 0 .

These estimates (shown in Table 1) suggest that a $1 \%$ increase in the growth rate of consumption translates into a net increase of $0.05 \%$ in the same variable after two years (i.e. the sum of $c^{S T}{ }_{11}$ and $\left.c^{S T}{ }_{12}\right)$. A $1 \%$ increase in the growth rate of wages will generate a $0.84 \%\left(c^{S T}{ }_{20}+c^{S T} T_{23}\right)$ net increase in the growth rate of consumption after 3 years. Also, a 1\% increase in the growth rate of profits raises consumption growth by $0.11 \%\left(c^{S T} 30\right)$ after three years. The speed of adjustment (from the short- to the long-term) is rather slow and takes place at a pace of $0.07 \%$ every year (the value of the coefficient $\left.c v^{C}\right)^{6}$.

\footnotetext{
${ }^{4}$ Unless otherwise specified, all exogenous variables included in all of the estimated equations are statistically significant. As a matter of simplicity, we do not show the parameters belonging to these items in the corresponding tables.

5 Stationarity is here confirmed by the battery of specification tests on the estimated error term (homoscedasticity, nonautocorrelation and normality).

${ }^{6}$ Note that, intuitively, this coefficient can be read as the dependency of the growth rate of consumption with respect to the difference between the observed (log) level of consumption and its fitted values (i.e. the corresponding error term) lagged one period. Its magnitude does not have a particular meaning, other than the fact that the higher its absolute value (though always necessarily less than 1) the speedier the adjustment between short and long-term deviations.
} 
This specification contains four exogenous binary variables (not shown in the table), which take the value of 1 in 1984, 1985, 2000 and 2008, and 0 otherwise. The associated parameters of these dummy variables are $-0.04,0.03,0.04$ and -0.07 , respectively. The parameter of the exogenous series $d 2008$ has the largest (absolute) value and can be seen as an atypically low growth rate of Chinese consumption that is not explained by the growth rate of worker's income or that of capitalists. Consumption growth in that year is $7 \%$ lower than that predicted by the postulated determinants.

Furthermore, the growth rate of both wages and consumption follow a downward trend after 2008. This is explained in part by an important increase in the average urban household saving rate which, from 1995 to 2008, went from 17 to about 28\% of disposable income (Prasad, 2011). Thus, we interpret 1995 as the beginning of the profit-led regime (see below for the discussion) and see the post-global financial crisis as the turning point of the demand regime which, following the slowdown of the Chinese economy due to lower world demand for manufactured goods, since then became wage-led. Some of the remaining specifications also present important exogenous breaks around that period, which confirm their significance as turning points.

$\ln C=c^{L T_{0}}+c^{L T_{1}} \ln W+c^{L T_{2}} \ln \Pi$

$\Delta \ln C=c^{S T_{0}+\Sigma} c^{S T}{ }_{1 i} \Delta \ln C_{-i}+\Sigma c^{S T} 2 i \Delta \ln W_{-i}+\Sigma c^{S T} 3 i \Delta \ln \Pi_{-i}+c v^{C}\left(\ln C_{-1}-c^{L T} T_{0} c^{L T}{ }_{1} \ln W_{-1}-c^{L T} 2 \ln \Pi_{-1}\right)$

Table 1. Consumption, dependent variable $\Delta \ln C$

\section{Investment}

Long-term total investment ${ }^{7}(I)$ is represented in equation 4 , and the parameter values found at the bottom of table 2 . The latter shows that, following a $1 \%$ increase in output $(Y)$ investment increases by $0.7 \%\left(I^{L T}\right)$, whereas a $1 \%$ increase in profits $(\Pi)$ yields a $0.3 \%\left(I_{2}^{L T_{2}}\right)$ increase in the same aggregate.

The corresponding re-parameterized short-term investment function is equation 5, whose estimated parameters are presented in table 2 . The results indicate that the conditional mean of the series is $-6 \%\left(I^{S T}\right)$, that a $1 \%$ increase in the growth rate of investment translates into a $0.2 \%\left(I^{S T}{ }_{11}\right)$ increase in the same series one year later, that a $1 \%$ rise in output growth makes investment growth increase by $0.77 \%\left(I^{S T} 20+I^{S T}{ }_{21}\right)$ after a year, and that when profits increase by $1 \%$ investment growth is stimulated by $0.22 \%\left(I^{S T} 30\right)$ in the same period. Also, notice that the interest rate (in level) is included in this specification, and that an increase in this variable leads to a fall in the growth

\footnotetext{
${ }^{7}$ Total investment is the sum of private and public enterprises. The privatization of part of state-owned enterprises, and the emergence of a new private sector (whose definition is not clearly established) makes uncertain the distinction between a public and a private sector. Onaran and Galanis have estimated a data series for private investment and profit while Molero-Simaro uses total investment. The former finds that an increase in the profit share has no significant effect on private investment although there is a positive effect on total investment. The latter finds that both output (Y) and profit ( $\Pi$ ) have a positive impact on total investment of the same magnitude (see Table 2). At the very least, these results show that profits do play a role in financing investment.
} 
rate of investment ${ }^{8}$. The speed of adjustment is comparable to the one we found for consumption $\left(c v^{I}=0.07\right)$.

This last specification contains two binary variables, one which equals 1 in 1994 and another one in 2009, and 0 otherwise. The parameter associated with $d 1994$ is -0.19 , which means that in that period (which marks the beginning of the profit-led regime) the growth rate of investment was not explained by either output growth or profit growth or the interest rate. The value of this parameter indicates that in 1994 investment growth (conditional on the determinants included in the corresponding equation) was atypically low, more specifically $19 \%$ lower than the conditional mean.

This exceptional behavior ${ }^{9}$ of investment growth is likely to have been the consequence of discretionary outward-looking macroeconomic and macro-prudential policy, which resulted in a lower (though steadier) dynamism of physical capital accumulation. This also contrasts with the higher rates of economic growth observed since the mid-nineties. Note that the growth rates of GDP and gross fixed capital formation are closer from 1995 onwards than before this period, and that investment growth in this country is the dominant source of GDP growth (Prasad, 2011). Since the break just described took place one year previous to the beginning of the structural change found in the consumption function described above, and given the double-digit growth rates observed in this economy since then, we empirically confirm that 1995 is the year in which the Chinese profit-led demand regime began.

$\ln I=I^{L T} T_{0} I^{L T} \ln Y+I^{L T}{ }_{2} \ln \Pi$

$\Delta \ln I=I^{S T} T_{0}+\Sigma I^{S T}{ }_{1 i} \Delta \ln I_{-i}+\Sigma I^{S T}{ }_{2 i} \Delta \ln Y_{-i}+\Sigma I^{S T} 3 i \Delta \ln \Pi_{-i}+\Sigma I^{S T}{ }_{4 i} r_{-i}+c v^{I}\left(\ln I_{-1}-I^{L T_{0}} I^{L T} \ln Y_{-1}-I^{L T} 2 \ln \Pi_{-1}\right)$

(5)

Table 2. Total investment, dependent variable $\Delta \ln I$

\section{Exports}

The long- and short-term specifications for exports $(X)$ are given by equations 6 and 7 . The former's estimates (table 3 ) suggest that a $1 \%$ rise in world imports $\left(M_{W}\right)$ brings about a $1.08 \%\left(x^{L T}\right)$ rise in the volume of exports, and that a $1 \%$ increase in relative export prices ${ }^{10}$ (domestic $P_{X} \mathrm{~V}$. foreign $\left.P_{X}\right)$ lowers the volume of exports by about $1.6 \%\left(x^{L T}\right)$.

The table also refers to the short-term estimates of the volume of exports. These results suggest that a $1 \%$ increase in the growth rate of world demand makes the growth rate of exports rise by $0.53 \%\left(x^{S T} 11\right)$ one year later, whereas a $1 \%$ increase in the growth rate of relative export prices lowers the growth rate of the volume of exports by $1.07 \%\left(x^{S T} 31\right)$. This more-than-proportional elasticity is explained by the dependency of the Chinese economy with respect to exports but is relatively dwarfed by a higher sensitivity of domestic prices with respect to import prices (see below). The conditional growth rate of exports is quite high $\left(x^{S T_{0}}=0.37\right)$, and the speed of adjustment is relatively low (0.07).

\footnotetext{
${ }^{8}$ Since the interest rate does not enter in logs in this specification, we cannot interpret the associated parameter $(-0.10)$ as an elasticity. In order to calculate the latter we would simply have to multiply $I^{S T} 40$ by the average interest rate.

${ }^{9}$ By exceptional we mean with respect to the postulated determinants of the corresponding equation.

${ }^{10}$ Ratios of this sort are multiplied by 100 in order to avoid having negative values for ratios lower than 1.
} 
This short-term specification contains 4 exogenous binary variables, which take the value of 1 in 1983, 1989, 2009 and 2010 ( 0 otherwise), with the associated parameter values being $-0.49,-0.44$, -0.36 and 0.37 , respectively. Note that the coefficients of $d 2009$ and $d 2010$ have opposite signs of almost the same magnitude, and account for the strong blow suffered by the growth rate of the volume of exports right after the global financial crisis, as well as the strong recovery afterwards to values observed prior to that shock. Neither world demand, nor relative prices explain these consecutive disturbances, even if the former follows the same pattern than exports right after the crisis. These shocks may be explained by, among others, a strong disruption in global value chains, which are not necessarily captured by demand-side variables.

$\ln X=x_{0}{ }^{L T}+x_{1}{ }^{L T} \ln M_{W}+x_{2}{ }^{L T} \ln \left(P_{X} / P_{X^{*}}\right)$

$\Delta \ln X=x_{0}{ }^{S T}+\Sigma x_{1 i}^{S T} \Delta \ln X_{-i}+\Sigma x_{2 i}^{S T} \Delta \ln M_{W-i}+\sum x_{3 i}^{S T} \Delta \ln \left(P_{X_{-i}} / P_{X^{*}-i}\right)+c v^{X}\left[\ln X_{-} x_{0}{ }^{L T}-x_{1}{ }^{L T} \ln M_{W}-\right.$ $\left.{ }_{2}^{L T} \ln \left(P_{X} / P_{X^{*}}\right)\right]$ (7)

Table 3. Exports, dependent variable $\Delta \ln X$

\section{Imports}

The equations determining the volume of imports (8 and 9) relate this aggregate to domestic demand (proxied by the volume of output, $Y$ ) and relative prices (the ratio of domestic prices $P$ v. import prices $P_{M}$ ). Table 4 indicates that the level of imports is strongly dependent on both, with high elasticities of about 1.7 in both cases $\left(m^{L T} 1\right.$ and $\left.m^{L T}\right)$. It is worth noting that imports are more elastic than exports in volume, despite trade barriers that have become more important since 2008 (Datt, Hoekman, \& Malouche, 2011).

The short-term specification reveals that a $1 \%$ increase in the growth rate of imports makes the same series increase $0.31 \%\left(m^{S T}{ }_{11}\right)$ the next period. For each percentage point of output growth there is a net increase in the growth rate of imports of $1.44 \%\left(m^{S T} 20+m^{S T}{ }_{21}\right)$ the year after. Also, a $1 \%$ rise in the growth rate of relative prices provokes a $0.45 \%\left(\mathrm{~m}^{S T} 30\right)$ increase in the same series. The speed of adjustment is higher than in the previous equations and takes place at $0.38 \%\left(c v^{M}\right)$ every period.

This equation contains 3 exogenous binary variables, which equal 1 in 1994, 2015 and 2016 (0 otherwise), and whose associated parameters are $-0.36,-0.23$ and -0.27 . The value of $d 1994$ suggests that in the corresponding year the growth rate of imports was $36 \%$ lower than that predicted by the determinants of this series. The fact that this dummy appears in this and other specifications with the highest (absolute) value, compared to the other binary variables, is an(other) indication of the deep changes in the structure of the Chinese economy that took place from then on. This atypical fall in import growth is perhaps related to the one observed in the investment growth equation, which may be due to the import substitution strategy (led initially by profits) implemented in this economy since then.

$\ln M=m_{0}{ }^{L T}+m_{1}{ }^{L T} \ln Y+m_{2}{ }^{L T} \ln \left(P / P_{M}\right)$

$\Delta \ln M=m_{0}{ }^{S T}+\sum m_{1 i}{ }^{S T} \Delta \ln M_{-i}+\sum m_{2 i}{ }^{S T} \Delta \ln Y_{-i}+\sum m_{3 i}{ }^{S T} \Delta \ln \left(P_{-i} / P_{M-i}\right)+c v^{M}\left[\ln M-m_{0}{ }^{L T}-m_{1}{ }^{L T} \ln Y-\right.$ $\left.m_{2}{ }^{L T} \ln \left(P / P_{M}\right)\right](9)$ 
Table 4. Imports, dependent variable $\Delta \ln M$

\section{Domestic prices}

Domestic prices (equations 10 and 11) are determined by import prices $\left(P_{M}\right)$ and unit labor costs $(U L C)$. Table 5 indicates that a $1 \%$ increase in the former yields a $14 \%\left(p^{L T}\right)$ rise in domestic prices, and that a $1 \%$ increase in the latter makes domestic prices rise by $2 \%\left(p^{L T}\right)$.

Note that the estimate for $p^{L T} 1$ seems to be quite high. However, taking into account that this is the channel via which foreign prices get transmitted onto domestic ones, such parameter value contains a measure of the exchange rate pass-through. According to Shu, Su and Chow (2008) the latter, after one year, for consumer prices is $11 \%$, for retail prices $15 \%$, for producer prices $29 \%$, for purchasing prices $39 \%$ and for import prices 63\%. The authors' estimates for the same series in the long-run are slightly higher. Our estimate lies well within that range (even somehow conservative with respect to the numbers just cited), in particular between those found for consumer and retail (that is, the relevant) prices.

The short-term specification states that a $1 \%$ increase in the inflation rate leads to a $0.6 \%$ $\left(p^{S T}{ }_{11}+p^{S T} 12\right)$ in the same series after two periods (i.e. inflation inertia lasts two years). A $1 \%$ rise in the growth rate of unit labor costs yields an increase of $0.26 \%\left(p^{S T}{ }_{31}\right)$ in inflation after a year has elapsed, and an increase in the interest rate leads to a fall in inflation ${ }^{11}$ the period after. The speed of adjustment between short and long-term is rather slow, both in absolute terms and compared to the previous models.

The latter contains four binary variables: d1988, d1993, d1994 and d2010. The associated parameter values are $-0.06,-0.07,-0.09$ and -0.06 . As in previous cases, the largest of these exogenous shocks takes place in 1994. This means that, once the postulated determinants of this aggregate are considered, in that period inflation was $9 \%$ lower than the conditional mean. This makes sense with respect to the previous findings about consumption and investment, which fell sharply in that period and are part and parcel of the strong drop in the inflation rate.

$\ln P=p_{0}{ }^{L T}+p_{1}{ }^{L T} \ln P_{M}+p_{2}{ }^{L T} \ln U L C$

$\Delta \ln P=p_{0}{ }^{S T}+\Sigma p_{1 i}{ }^{S T} \Delta \ln P_{-i}+\Sigma p_{1 i}{ }^{S T} \Delta \ln P_{M-i}+\Sigma p_{2 i}{ }^{S T} \Delta \ln U L C_{-i}+\Sigma p_{3 i}{ }^{S T} r_{-i}+c v^{P}\left(\ln P_{-1}-p_{0}{ }^{L T}-p_{1}{ }^{L T} \ln P_{M-1}-\right.$ $\left.p_{2}{ }^{L T} \ln U L C-1\right) \quad(11)$

Table 5. Price deflator. Dependent variable $\Delta \ln P$

\section{Export prices}

Export prices (equations 12 and 13) are determined by domestic prices $(P)$ and foreign export prices $\left(P_{X}\right)$. When domestic prices increase by $1 \%$ export prices move up by $0.1 \%\left(p_{X}{ }^{L T} 1\right)$ and when foreign prices rise by $1 \%$ Chinese export prices increase by $0.9 \%\left(p_{X}{ }^{L T} T_{2}\right)$. Note that the sum of

\footnotetext{
${ }^{11}$ This is likely to have a double effect. On the one hand, the straightforward link between the interest rate and inflation (i.e. higher/lower saving when the interest rate increases/decreases). On the other hand, perhaps more relevant at a global scale, the changes in the exchange rate that movements in the interest rate provoke and that are translated into changes in inflation via the pass-through effect (see Shu, Su and Chow, 2008).
} 
these two coefficients is close to 1 , and that $p_{x}{ }^{L T} 2>p_{X}{ }^{L T} 1$, which suggests that China is a pricetaker in export markets.

The conditional mean of the growth rate of export prices is $-4 \%\left(p_{X} S T_{0}\right)$. When this series increases by $1 \%$, inertia takes place by pushing down export prices by $0.5 \%\left(p_{X}{ }^{S T} T_{11}+p_{X}{ }^{S T}{ }_{12}\right)$. A $1 \%$ increase in domestic inflation comes along with a net increase of $0.08 \%\left(p_{X}{ }^{S T}{ }_{20}+p_{X}{ }^{S T}{ }_{21}\right)$ in export price growth one year later. Also, a $1 \%$ increase in foreign export prices growth generates a $0.3 \%\left(p_{X} T_{30}\right)$ increase in the same aggregate in the same period. Finally, the speed of adjustment from the shortto the long-term takes place at an unusually fast pace, $0.72 \%\left(c v^{P X}\right)$ every year.

Apart from the constant term (i.e. the conditional mean) the previous specification contains four binary variables: $d 1985, d 2004, d 2009$ and a structural change dummy that goes from 1995 to the end of the sample period. The associated parameter values are $0.08,0.04,-0.1$ and 0.03 . The coefficient of $d 2009$ says that in such period the growth rate of export prices was not explained by either domestic or foreign prices, but by another factor not included in the specification. The latter could be related to policy reactions from competing economies that strongly made Chinese export prices fall $10 \%$ below the average ( $-4 \%$ found here). The structural change dummy indicates that, since 1995, export prices grow at a higher pace than before that year. The inclusion and statistical significance of this variable is indicative of the pressure these prices are exposed to ever since they compete worldwide.

$\ln P_{X}=p_{X 0}{ }^{L T}+p_{X 1}{ }^{L T} \ln P+p_{X 2}{ }^{L T} \ln P_{X}{ }^{*}$

$\Delta \ln P_{X}=p_{X 0}{ }^{S T}+\Sigma p_{X 1 i}{ }^{S T} \Delta \ln P_{X-i}+\sum p_{X 2 i}{ }^{S T} \Delta \ln P_{-i}+\sum p_{X 3 i}{ }^{S T} \Delta \ln P_{X-i}+c v^{P}\left(\ln P_{X-1}-p_{X 0}{ }^{L T}-p_{X 1}{ }^{L T} \ln P_{-1}-\right.$ $p_{X 2}{ }^{L T} \ln P_{\left.X^{*}-1\right)} \quad$ (13)

Table 6. Export price. Dependent variable $\Delta \ln P_{X}$

\section{Marginal effects and summary of results}

In order to compute the overall effect of a change in output given a change in the wage share, we first calculate the parameter $h_{1}$, which is the sum of the partial derivatives of consumption, investment and imports with respect to output multiplied by the ratios of the series involved (see Table 7). Next we calculate the sum of the partial derivatives of consumption, investment and net exports with respect to the labor share, which we call $h_{2}$. In order to get to the parameters, we are interested in, we follow the formulation by Stockhammer and Onaran (2012) described below (see Table 8).

\section{Table 7. Elasticities of $C, I$ and $M$ with respect to $Y$}

The estimated parameters of equations 3, 5, 7, 9, 11 and 13 (which contain information about both the short- and the long-term) are used in the calculation of $h_{1}$ and $h_{2}$, shown in tables 7 and 8 . In order to compute the marginal effects from the parameters estimated (all in logs) shown in table 7 we multiply these by their corresponding ratios. The sum of the marginal effects $\partial C / \partial Y, \partial I / \partial Y$ less $\partial M / \partial Y$ is the overall marginal effect which, as expected, is positive and lies between 0 and 1 .

The computation of the multiplier results from this and is calculated as $1 /\left(1-h_{1}\right)$. Our results indicate that this figure is (as expected) larger than 1 and higher than the one found in Onaran and 
Galanis (2012) ${ }^{12}$. This is a natural by-product of the fact that $h_{1}$ (i.e. the partial effects of changes in income on consumption, investment and imports) is higher than the one found in that study. Therefore, any changes affecting the determinants of aggregate demand entering the right-hand side of the national income identity are more important in our analysis than in theirs. This difference may be due to the fact that the period we consider goes beyond 2007, and thus takes into account the post-crisis behavior of demand. As we showed in the introduction, the post-crisis fall in foreign demand has been accompanied by important declines in economic growth in China. A potential candidate for filling up this gap between supply and demand is personal consumption, which will in turn be enhanced by the multiplier.

\section{Table 8. Effects of a $1 \%$ increase in the labor share}

The marginal effects of a $1 \%$ increase in the wage share, shown in table 8 , have the expected signs and magnitudes. The internal effects of an increase in the labor share are positive and quite close to those found by Onaran and Galanis (2012). However, note that the authors get a lower figure for the effects on consumption than us $(0.41 \mathrm{v}$. 0.63$)$ and that they do not withhold their significant estimate of the effect of profits on total investment, but prefer to retain the absence of effect on private investment. Molero-Simaro (2015), in contrast, gets an effect on investment which is comparable to ours $(-0.22$ v. -0.24$)$. However, the effect on consumption he found is much lower than ours (0.29).

The external effects found by Molero-Simaro are close to ours, and both contrast starkly with the result found by Onaran and Galanis which is very strong. This difference explains why our finding that the Chinese economy is wage-led differs from theirs whereby this economy is profit-led. For them a $1 \%$ increase in the labor share brings about a fall of $2 \%$ in net exports (explained in part by their finding that $e_{P, U L C}=0.71$, which contrasts with 0.26 we found), whereas for us such a change in the wage share would bring about a fall of $0.06 \%$ in the same aggregate.

Overall, we find that a $1 \%$ improvement of the wage share leads to a $0.48 \%$ increase of the GDP while for Onaran and Galanis (2012) the effect was strongly negative (-1.95). Clearly, the Chinese economy is now wage-led.

\section{Discussion}

Our results show that, since the great recession, China turned into a wage-led demand regime. This is the outcome of a structural change of the Chinese economy which is explained by a change of various behavioral components as well as the size of the components of aggregate demand. The short-term specification of the consumption function indicates that the propensity to consume out of wages $(0.84 \%)$ is much higher than the propensity to consume out of profits $(0.11 \%)^{13}$. The growth of investment is highly sensitive to output growth $(0.7 \%)$ and much less to profits $(0.3 \%)$ both in the short and long term. The positive elasticity to profits is probably explained by the rise of the private sector, which in the industrial sector in 2015-2016 accounts for 55\% of total investments, earns at least twice as much profits than state-owned enterprises, and have a return

\footnotetext{
${ }^{12}$ Unfortunately, comparison with Molero-Simaro (2015) is not possible, given that the author does not present the results of $h_{1}$ and the multiplier.

${ }^{13}$ On the long term, the two propensities are not too different (respectively $0.49 \%$ and $0.44 \%$ ) but the speed of adjustment from the short to the long term is slow (see Table 1).
} 
on assets three times higher (Lardy, 2016; Lardy \& Huang, 2016). The export price elasticity is higher than unity but rather low (-1.07\%). These behavioral components match the characteristics of a wage-led demand regime as described by Lavoie and Stockhammer (2013, p. 24) and Onaran $(2016)^{14}$. The evolution of the relative size of the components of aggregate demand also contributes to the shift in demand regime. Not only has households' consumption risen and investment declined, but trade openness has decreased, with exports and imports in 2016 accounting for less than $20 \%$ of GDP, down from respectively $35 \%$ and $28 \%$ in 2007 before the great recession. This is two times less than the European Union for the same year.

The change in the behavioral components can be explained by the evolution of the following features of the Chinese economy. The surge in real wages, which doubled between 2008 and $2017^{15}$ (ILO, 2019), are due to market-led wage increases and policy changes. China has passed the Lewis turning point and the era of surplus labor is over (Yuming, Jingjing, \& Changrong, 2018; Zhang, Yang, \& Wang, 2011; Cai \& Du, 2011). Concretely, the population is aging, and labor has started to shrink, which in the long-term plays in favor of real wage hikes. The increase of the minimum wage on 2004 had a "cleansing effect of labor market standards", forcing incumbent firms to strengthen their productivity and competitiveness (Mayneris, Poncet, \& Zhang, 2014). The introduction of the new labor contract law, which came into effect in 2008, "has reversed the trend toward increasing informalization of the urban labor market" (Gallagher, Giles, Park, \& Wang, 2015). It has improved the bargaining power of workers and their social insurance coverage and benefits (Cheng, Smyth, \& Guo, 2015), including for the migrant workers (Gao, Yang, \& Li, 2012). Lee (2016) contests these points and argues that these structural and institutional changes have not empowered workers to the point that they would be more conscious of their rights and be more assertive. Nonetheless, he agrees that "striking workers demands for higher wages have been met with state toleration and implicit support, because they dovetail the state's macroeconomic restructuring strategy" of rebalancing growth (Lee, 2016, p 326). These combined evolutions explain the improvement of the wage share after the great recession.

Finally, the GDP growth slows down, which stems from the success of the Chinese economic development, and the recent shift away from exports and investment towards consumption, has made China's economy less import-intensive. Households' consumption of goods is less importintensive than exports and investment (Hong, Lee, Liao, \& Seneviratne, 2017). This compositional effect is followed by an import substitution effect, in particular in electronics, which see Chinese companies producing capital and intermediate goods more locally that used to be imported ${ }^{16}$. The authors' calculations reveal that "the rebalancing accounts for about half of the actual import slowdown” (Hong et al., 2017, p. 20).

Households' consumption has therefore an effect on all components of aggregate demand, which explains its key role has as a driver of rebalancing Chinese growth. However, there are limitations

\footnotetext{
${ }^{14}$ Although imperfectly: for instance, Chinese imports are highly sensitive to domestic demand, respectively $1.7 \%$ and $1.43 \%$ on the long and short term (see Table 4), while, net export price elasticity and import income elasticity are expected to be low in a wage-led regime.

15 This the highest growth registered in any developing country over the period. In India, real wages have increased by around 55\% and in Indonesia by around 45\%. Source: Authors' calculation with ILO Global Wage Report 2018 data.

${ }^{16}$ The ratio of processing imports to total exports has fallen from $35 \%$ in 2003 to $20 \%$ in 2015. Source: Hong et al., p. 13.
} 
to the structural change described above which indicate that the rise of households' consumption is still not firmly grounded. The first is that households still have to accumulate precautionary savings because the social security system is still restricted to a minority of the population, in particular those who work for the state and state-owned enterprises.

China dedicates only around $8 \%$ of its GDP on social expenses versus $20 \%$ on average for OECD countries (IMF, 2018, p. 17). Its effect on the redistribution of income is small: $8.8 \%$ in 2016 against $30 \%$ on average in Europe ${ }^{17}$ (Li, 2016, p. 210). As a consequence, households who earn enough, have to involuntarily save for healthcare, education, pension, housing and unemployment (Gu, Tam, Li, \& Zhao, 2018). Increasing social expenses equitably by $1 \%$ “...would result in a permanent increase in the household consumption ratio of $1 \frac{1 / 4}{4}$ percentage points of GDP" (Baldacci et al., 2010, p. 20).

Since the $13^{\text {th }}$ five-year plan, Chinese authorities have a plan to establish a comprehensive, equitable and unified pension system covering both urban and rural residents that is yet to be seen. Another potential limit is the rise of consumer debt which, in December 2018, reached an all-time high at $53.2 \%$ of GDP from $17.9 \%$ in $2008^{18}$. Compared to other countries, the level of households' debt is not yet worrying, but its high rate of growth shows that it could soon become a problem.

\section{Conclusion}

The main policy conclusion that we can draw from the shift from a profit-led to a wage-led demand regime is that Chinese authorities can now implement a pro-labor policy as a strategy that will stimulate growth and help rebalancing the economy towards consumption, and can ultimately lead to reduce inequality, as measured by the Gini Index (Molero-Simaro, 2017). This involves letting real wages rise at a higher rate than productivity until the labor share recovers its past level, and then making sure that their future growth become synchronized. This implies a wage policy that reduces the gap in the wage scale, increases regularly the real minimum wage and monitors its implementation, and gives the necessary space to independent trade unions for collective bargaining. Increasing social spending to the level of OECD countries to support the reform of the social security system will complement the wage policy. This reform should extend the coverage to rural and informal workers. This set of measures will contribute to the reduction of social inequalities and ensure that effective demand stays at a high level without leading households to over indebtedness ${ }^{19}$. Public investment policy should be more diversified and on top of infrastructure (utilities and transportation) should give more emphasis to public services, as well as personal services which have the potential to create unoffshorable skilled jobs provided by small and medium enterprises of the private sector. Deindustrialization and the expansion of the tertiary sector is already under way in China and can potentially reduce the energy and carbon intensity of output as well as air pollution providing that the state implements adequate public policies that go

\footnotetext{
17 This is measured by the difference between the Gini index of the market income (primary income) and the Gini index of the disposable income after redistribution due to social security and welfare.

18 Source: IMF, Global debt data base, accessed on $25 \quad$ January 2018. https://www.imf.org/external/datamapper/HH_LS@GDD/CHN?year=2017

${ }^{19}$ Molero-Simarro (2017) concludes that the slight recovery of the wage share he observed in the post-crisis period (2008-2014), led to a less unequal income distribution among urban households and to a decline of the overall Gini index.
} 
in that sense. In summary, rebalancing the economy is the opportunity to relaunch the Chinese economy on a new basis that may solve several economic, social and environmental issues.

\section{Appendix}

All the data come from the World Development Indicators, the World Bank, expressed in constant 2010 US dollars, with the exception of the price levels of exports and of imports that are taken from Penn World Table - international comparisons of production, income and prices 9.0. and the calculations of the labor share which is based on data from the National Bureau of Statistic of China (NBS).

The labor share is calculated as the compensation of employees divided by the Gross Domestic product by income approach. We use the regional data (Gross Regional product by income approach) that we sum up to obtain the total at national level. To avoid any discrepancy, the labor share is applied to the GDP by expenditure approach of the World Development Indicators.

Because of the changes in accounting method of the NBS in the estimation of the compensation of employees, we have followed the corrections operated by Qian (2014). In short, during the period of 2004-2007, all income excluding depreciation and net production tax in agriculture is counted as labor compensation, while it was counted as profit before. In urban areas, the mixed income of self-account workers is counted as operating surplus while it was counted as labor compensation before. According to Bai and Qian (2010), the overall effect was an overestimation of the fall of the labor share during the period. Qian (2014) recalculates the mixed income of selfaccount workers for the period 2004-2011, and eliminates the accounting method change for both farmers and urban workers so that the data series for compensation of employees after 2004 is coherent with the official GDP by income approach before 2004 (Table 5, panel E, adjustment 3 in Qian, 2014, p 11). Finally, we have observed that the new data for compensation of employees and GDP by income approach published by NBS in 2018, gives a wage share very close to the estimation of Qian (2014) - the difference is around 1\%- for the years 2009-2011. For this reason, we have adopted Qian's estimation of the labor share for the years 2004-2007, and the data series published in 2018 by the NBS for the years 1978-2003 and 2008-2016. The wage share can be seen in Figure 2. The dataset is available on the website of the China Economic Review. 


\section{References}

Bai C., Qian Z., (2010). Factor income distribution in China: 1978-2007. China Economic Review, 21(4), 650-670. Retrieved from https://doi.org/10.1016/j.chieco.2010.08.004

Baldacci, E., Callegari, G., Coady, D., Ding, D., Kumar, M., Tommasino, P., \& Woo, J. (2010). Public Expenditures on Social Programs and Household Consumption in China. IMF Working Paper, Fiscal Affairs Department. Working Paper. IMF. Washington DC. Retrieved from https://ssrn.com/abstract=1578667

Bhaduri, A., \& Marglin, S. (1990). Unemployment and the real wage: the economic basis for contesting political ideologies. Cambridge Journal of Economics, 14(4), 375-393. Retrieved from http://www.jstor.org/stable/23598376

Blanchard, O., \& Giavazzi, F. (2006). Rebalancing growth in China: A three-handed approach. China \& World Economy, 14(4), 1-20. Retrieved from https://doi.org/10.1111/j.1749-124X.2006.00027.x

Cai, F., \& Du, Y. (2011). Wage increases, wage convergence, and the Lewis turning point in China. China Economic Review, 22(4), 601-610. Retrieved from https://doi.org/10.1016/j.chieco.2011.07.004

Cheng, Z., Smyth, R., \& Guo, F. (2015). The impact of China's new Labour Contract Law on socioeconomic outcomes for migrant and urban workers. Human Relations, 68(3), 329-352. Retrieved from https://doi.org/10.1177\%2F0018726714543480

Datt, M., Hoekman, B., \& Malouche, M. (2011). Taking stock of trade protectionism since 2008. Economic Premise, 72(December).

Gallagher, M., Giles, J., Park, A., \& Wang, M. (2015). China's 2008 Labor Contract Law: Implementation and implications for China's workers. Human Relations, 68(2), 197-235. Retrieved from https://doi.org/10.1177\%2F0018726714543480

Gao, Q., Yang, S., \& Li, S. (2012). Labor contracts and social insurance participation among migrant workers in China. China Economic Review, 23(4), 1195-1205. Retrieved from https://doi.org/10.1016/j.chieco.2012.09.002

Gu, X., Tam, P. S., Li, G., \& Zhao, Q. (2018). An alternative explanation for high saving in China: Rising inequality. International Review of Economics \& Finance. Retrieved from https://doi.org/10.1016/j.iref.2018.12.004

Hong, G. H., Lee, J., Liao, W., \& Seneviratne, D. (2017). China and Asia in global trade slowdown. Journal of International Commerce, Economics and Policy, 8(01), 1750001. Retrieved from https://doi.org/10.1142/S1793993317500016

ILO. (2019). Global Wage Report 2018/19. Retrieved from Geneva: https://www.ilo.org/global/research/globalreports/global-wage-report/2018/lang--en/index.htm

IMF. (2018). People's Republic of China 2018 Article IV Consultation. Retrieved from https://www.imf.org/en/Publications/CR/Issues/2018/07/25/Peoples-Republic-of-China-2018-Article-IVConsultation-Press-Release-Staff-Report-Staff-46121

Jetin, B., \& Kurt, O. E. (2016). Functional income distribution and growth in Thailand: A post Keynesian econometric analysis. Journal of Post Keynesian Economics, 39(3), 334-360. Retrieved from https://doi.org/10.1080/01603477.2016.1202774

Lardy, N. (2016). The Changing Role of the Private Sector in China. In R. B. o. Australia (Ed.), Structural Change in China: Implications for Australia and the World. Canberra: Reserve Bank of Australia. Retrieved from https://ideas.repec.org/h/rba/rbaacv/acv2016-04.html

Lardy, N. R., \& Huang, Z. (2016). Resurgence of State-Led Growth in China? Retrieved from https://piie.com/blogs/china-economic-watch/resurgence-state-led-growth-china

Lavoie, M., \& Stockhammer, E. (2013). Wage-led Growth: An equitable strategy for economic recovery: Palgrave Macmillan. Retrieved from https://www.palgrave.com/gp/book/9781137357922

Lee, C.K., (2016). Precarization or empowerment? Reflections on recent labor unrest in China. The Journal of Asian Studies, 75(2), 317-333. Retrieved from https://doi.org/10.1017/S0021911815002132

Lemoine, F., \& Unal, D. (2017). China's Foreign Trade: A "New Normal”. China \& World Economy, 25(2), 1-21. Retrieved from https://doi.org/10.1111/cwe.12191

Li, S. (2016, 2016). Redistributive effects of social security system in China. Paper presented at the EU-China Social Protection Reform Project, Beijing, Diaoyutai Hotel. Retrieved from https://eeas.europa.eu/delegations/fiji/15471/eu-china-social-protection-reform-project-2016-high-levelevent_ko 
Mayneris, F., Poncet, S., \& Zhang, T. (2014). The cleansing effect of minimum wage: Minimum wage rules, firm dynamics and aggregate productivity in China. CEPII Working, No. Paper, 16. Retrieved from https://ideas.repec.org/p/cii/cepidt/2014-16.html

Molero-Simarro, R. (2017). Inequality in China revisited. The effect of functional distribution of income on urban top incomes, the urban-rural gap and the Gini index, 1978-2015. China Economic Review, 42(2017), 101-117. Retrieved from https://doi.org/10.1016/j.chieco.2016.11.006

Molero-Simarro, R. (2015). Functional distribution of income, aggregate demand, and economic growth in the Chinese economy, 1978-2007. International Review of Applied Economics, 29(4), 1-20. Retrieved from https://doi.org/10.1080/02692171.2015.1016404

Onaran, Ö. (2016). Wage-versus profit-led growth in the context of globalization and public spending: the political aspects of wage-led recovery. Review of Keynesian Economics, 4(4), 458-474. Retrieved from https://doi.org/10.4337/roke.2016.04.07

Onaran, Ö., \& Galanis, G. (2012). Is aggregate demand wage-led or profit-led? National and Global Effects',(International Labour Office, Geneva 2012) Conditions of Work and Employment Series(31). Retrieved from https://ideas.repec.org/p/ilo/ilowps/994786233402676.html

Prasad, E. S. (2011). Rebalancing growth in Asia. International Finance, 14(1), 27-66. Retrieved from https://doi.org/10.1111/j.1468-2362.2011.01276.x

Qian, Z. (2014). Implications of GDP accounting for factor income share in China. China Economic Review, 30, 370-

382. Retrieved from https://doi.org/10.1016/j.chieco.2014.06.012

Setterfield, M. (2016). Wage-versus profit-led growth after 25 years: an introduction. Review of Keynesian Economics, 4(4), 367-372. Retrieved from https://www.elgaronline.com/view/journals/roke/4-4/roke.2016.04.01.xml

Shu, C., Su, X., \& Chow, N. (2008). Exchange rate pass-through in Mainland China. China Economic Issues, 8(1).

Stockhammer, E., Onaran, Ö., \& Ederer, S. (2008). Functional income distribution and aggregate demand in the Euro area. Cambridge journal of Economics, 33(1), 139-159. Retrieved from https://doi.org/10.1093/cje/ben026

Yuming, C., Jingjing, M., \& Changrong, L. (2018). Recent developments in China's labor market: Labor shortage, rising wages and their implications. Review of Development Economics, 22(3). Retrieved from https://doi.org/10.1111/rode.12391

Zhang, L. (2016). Rebalancing in China-Progress and Prospects. IMF Working Paper, 16(183). Retrieved from https://ssrn.com/abstract=2882621

Zhang, X., Yang, J., \& Wang, S. (2011). China has reached the Lewis turning point. China Economic Review, 22(4), 542-554. Retrieved from https://doi.org/10.1016/j.chieco.2011.07.002

Zhao, S., Zhan, H., Jiang, Y., \& Pan, W. (2017). How big is China's real estate bubble and why hasn't it burst yet? Land Use Policy, 64, 153-162. Retrieved from https://doi.org/10.1016/j.landusepol.2017.02.024 


\section{Figures and tables}

Figure 1: Structure of China's demand, 1998-2017

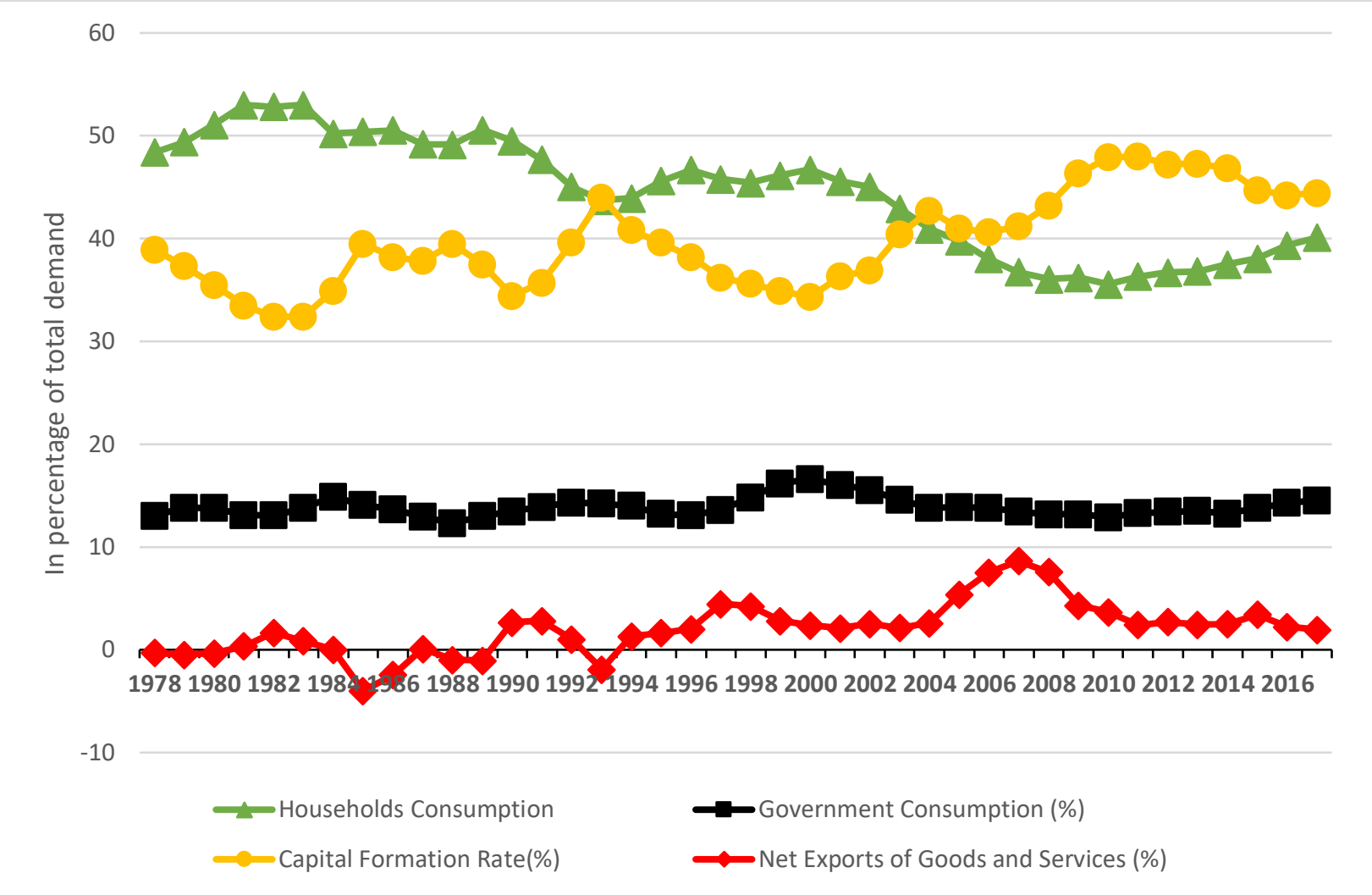

Data Source: Authors' computation with data from National Bureau of Statistics of China. 
Figure 2: Labor income and household consumption in China, 1978-2016

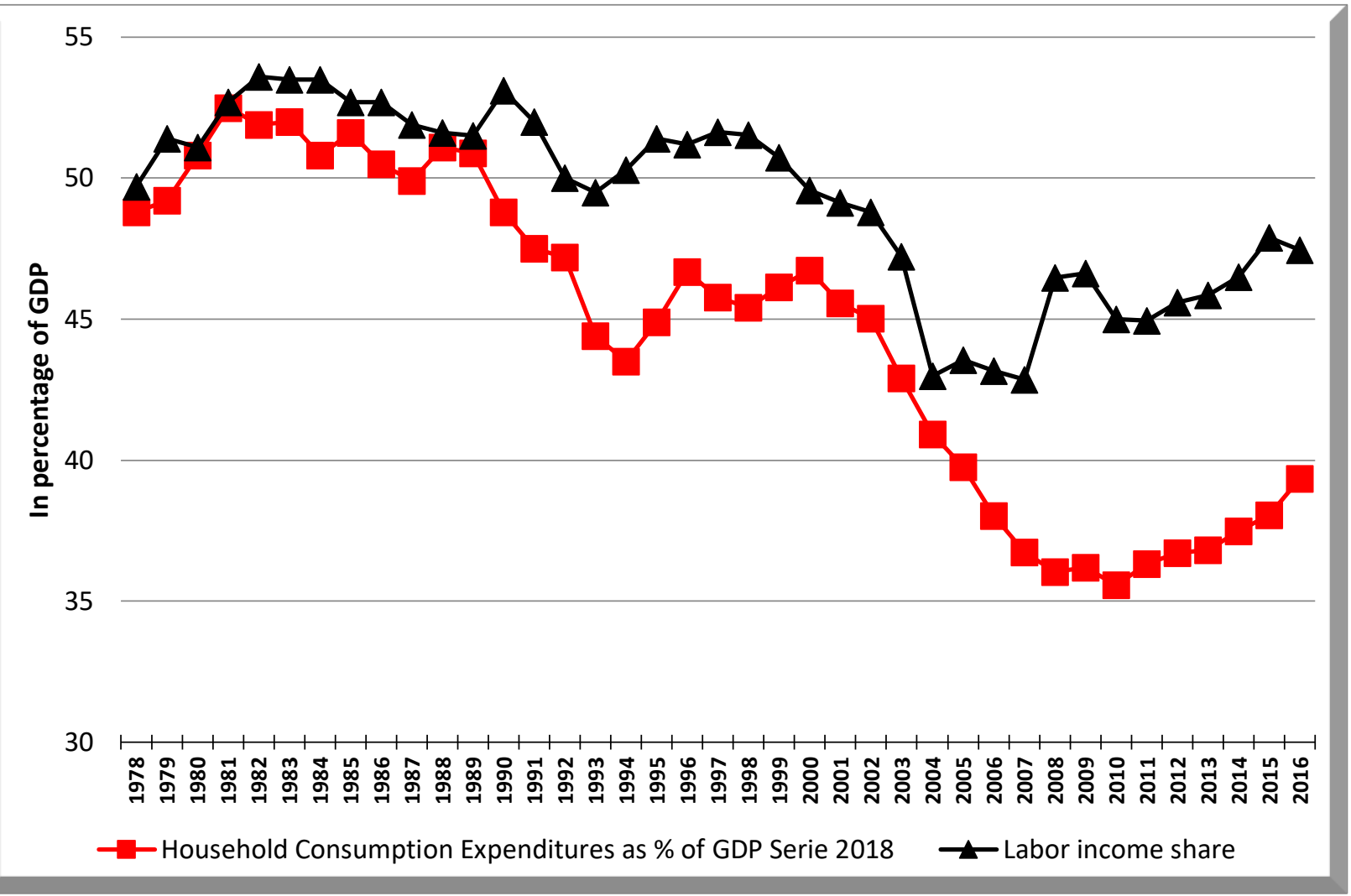

Data Source: Author's calculations with data from National Bureau of Statistics of China. 
Table 1. Consumption, dependent variable $\Delta \ln C$

\begin{tabular}{|c|c|c|c|}
\hline Coefficient of: & $\begin{array}{c}\text { Our estimates } \\
1978-2016\end{array}$ & $\begin{array}{c}\text { Onaran-Galanis } \\
1980-2007\end{array}$ & $\begin{array}{c}\text { Molero-Simaro }(1 b) \\
1978-2007\end{array}$ \\
\hline Constant & & $\begin{array}{c}-0.011 \\
(-0.583)\end{array}$ & $\begin{array}{l}0.000 \\
(0.19)\end{array}$ \\
\hline$\Delta \ln C_{-1}$ & $\begin{array}{c}0.187 \\
(3.808)^{* * *}\end{array}$ & & $\begin{array}{l}-0.098 \\
\text { (N/A) }\end{array}$ \\
\hline$\Delta \ln C_{-2}$ & $\begin{array}{c}-0.139 \\
(-2.723)^{* *}\end{array}$ & & \\
\hline$\Delta \ln W$ & $\begin{array}{c}0.744 \\
(8.326)^{* * *}\end{array}$ & $\begin{array}{c}0.428 \\
(1.923)^{*}\end{array}$ & $\begin{array}{c}0.730 \\
(36.49)^{* * *}\end{array}$ \\
\hline$\Delta \ln W_{-1}$ & & $\begin{array}{c}0.326 \\
(1.643)^{*}\end{array}$ & $\begin{array}{l}0.015 \\
(0.78) \\
\end{array}$ \\
\hline$\Delta \ln W_{-3}$ & $\begin{array}{c}0.109 \\
(2.936)^{* * *} \\
\end{array}$ & & \\
\hline$\Delta \ln \Pi$ & $\begin{array}{c}0.114 \\
(1.531) \\
\end{array}$ & $\begin{array}{c}0.427 \\
(3.731)^{* * *}\end{array}$ & $\begin{array}{c}0.162 \\
(9.24) * * * \\
\end{array}$ \\
\hline$\Delta \ln \Pi_{-1}$ & & $\begin{array}{c}-0.186 \\
(-1.571)\end{array}$ & $\begin{array}{l}-0.027 \\
(-1.59)\end{array}$ \\
\hline$V C_{-1}$ & $\begin{array}{c}-0.073 \\
(1.731)^{*}\end{array}$ & & \\
\hline
\end{tabular}

$V C_{-1} \quad \rightarrow \ln C_{-1}-0.322-0.495 \ln W_{-1}-0.448 \ln R_{-1}$

t-stats $\rightarrow-4.379 * * *,-4.086 * * *,-3.899 * * *$ 
Table 2. Total investment, dependent variable $\Delta \ln I$

\begin{tabular}{|c|c|c|c|}
\hline Coefficient of: & $\begin{array}{c}\text { Our estimates } \\
1978-2016\end{array}$ & $\begin{array}{c}\text { Onaran-Galanis } \\
1980-2007\end{array}$ & $\begin{array}{c}\text { Molero-Simaro }(2 b) \\
1978-2007\end{array}$ \\
\hline \multirow{2}{*}{ Constant } & $\begin{array}{c}-0.061 \\
(-2.497)^{*}\end{array}$ & $\begin{array}{c}-0.061 \\
(-0.549)\end{array}$ & $\begin{array}{c}-0.006 \\
(-0.42)\end{array}$ \\
\hline \multirow{2}{*}{$\Delta \ln I_{-1}$} & $\begin{array}{c}0.182 \\
(1.451)\end{array}$ & $\begin{array}{c}-0.184 \\
(-0.786)\end{array}$ & $\begin{array}{c}-0.244 \\
(\mathrm{~N} / \mathrm{A})\end{array}$ \\
\hline \multirow{2}{*}{$\Delta \ln Y$} & $\begin{array}{c}1.219 \\
(4.522)^{* * *}\end{array}$ & $\begin{array}{c}2.405 \\
(1.741)\end{array}$ & $\begin{array}{c}0.592 \\
(7.99)^{* * *}\end{array}$ \\
\hline \multirow{2}{*}{$\Delta \ln Y_{-1}$} & $\begin{array}{c}-0.449 \\
(-2.943)^{* * *}\end{array}$ & & 0.089 \\
& 0.222 & -1.642 & 0.565 \\
\hline \multirow{2}{*}{$\Delta \ln \Pi$} & $(0.936)$ & $(-1.153)$ & $(8.19)^{* * *}$ \\
\hline \multirow{2}{*}{$\Delta \ln \Pi_{-1}$} & & & -0.053 \\
& & & $(-0.80)$ \\
\hline$r$ & -0.106 & & \\
\hline \multirow{2}{*}{$\Delta \ln I g_{-1}$} & $(-2.256)^{* *}$ & & \\
\hline \multirow{2}{*}{$V C_{-1}$} & -0.067 & & \\
\hline
\end{tabular}

$r$ stands for the real interest rate and $I_{G}$ for public investment

$V C_{-1} \rightarrow \ln I_{-1}-0.694 \ln Y_{-1}-0.285 \ln \Pi_{-1}$

t-stats $\rightarrow-4.359^{* * *},-1.639^{*}$ 
Table 3. Exports, dependent variable $\Delta \ln X$

\begin{tabular}{|c|c|c|c|}
\hline Coefficient of: & $\begin{array}{c}\text { Our estimates } \\
1978-2016\end{array}$ & $\begin{array}{c}\text { Onaran-Galanis } \\
1980-2007\end{array}$ & $\begin{array}{c}\text { Molero-Simaro }+(3 b) \\
1978-2007\end{array}$ \\
\hline Constant & $\begin{array}{c}0.373 \\
(4.624)^{* * *}\end{array}$ & $\begin{array}{c}0.01 \\
(0.195)\end{array}$ & $\begin{array}{c}-0.028 \\
(-5.46) * * *\end{array}$ \\
\hline$\Delta \ln X_{-1}$ & $\begin{array}{c}0.53 \\
(4.463) * * *\end{array}$ & $\begin{array}{c}0.396 \\
(2.556) * *\end{array}$ & $\begin{array}{l}0.051 \\
(\mathrm{~N} / \mathrm{A})\end{array}$ \\
\hline$\Delta \ln \left(P_{X-1} / P_{X^{*-1}}\right)$ & $\begin{array}{c}-1.072 \\
(-3.086) * * *\end{array}$ & & \\
\hline$\Delta \ln R U L C$ & & $\begin{array}{c}-1.175 \\
(-3.2) * * *\end{array}$ & $\begin{array}{c}-0.166 \\
(-5.52)^{* * *}\end{array}$ \\
\hline$\Delta \ln Y r w$ & & $\begin{array}{c}2.584 \\
(1.742)^{*}\end{array}$ & $\begin{array}{l}0.041 \\
(0.65)\end{array}$ \\
\hline$\Delta \ln Y r w-1$ & & & $\begin{array}{l}0.023 \\
(0.42) \\
\end{array}$ \\
\hline$\Delta \ln Y$ & & & $\begin{array}{c}-0.379 \\
(12.45)^{* * *}\end{array}$ \\
\hline$\Delta \ln Y_{-1}$ & & & $\begin{array}{c}-0.148 \\
(-4.9)^{* * *}\end{array}$ \\
\hline$\Delta \ln x r$ & & & $\begin{array}{l}-0.031 \\
(-0.43)\end{array}$ \\
\hline$\Delta \ln x r_{-1}$ & & & $\begin{array}{l}-0.036 \\
(-0.61)\end{array}$ \\
\hline$V C_{-1}$ & $\begin{array}{c}-0.069 \\
(-3.558) * * *\end{array}$ & & \\
\hline
\end{tabular}

$\dagger$ The dependent variable in this specification is net exports, and includes prices and volumes simultaneously

$V C_{-1} \rightarrow \ln X_{-1}-1.085 \ln M_{W-1}+1.572 \ln \left(P_{X-1} / P_{X^{*}-1}\right)$

t-stats $\rightarrow-3.682 * * *, 2.672 * * *$ 
Table 4. Imports, dependent variable $\Delta \ln M$

\begin{tabular}{|c|c|c|}
\hline Coefficient of: & $\begin{array}{c}\text { Our estimates } \\
1978-2016\end{array}$ & $\begin{array}{c}\text { Onaran-Galanis } \\
1980-2007\end{array}$ \\
\hline$\Delta \ln M_{-1}$ & $\begin{array}{c}0.312 \\
(3.259)^{* * *}\end{array}$ & $\begin{array}{c}0.333 \\
(2.192)^{* *}\end{array}$ \\
\hline$\Delta \ln Y$ & $\begin{array}{c}2.428 \\
(11.703)^{* * *}\end{array}$ & \\
\hline$\Delta \ln Y_{-1}$ & $\begin{array}{c}-0.999 \\
(-5.068) * * *\end{array}$ & $\begin{array}{c}2.69 \\
(3.869)^{* * *}\end{array}$ \\
\hline$\Delta \ln \left(P_{-1} / P m_{-1}\right)$ & $\begin{array}{c}0.455 \\
(2.089)^{* *}\end{array}$ & $\begin{array}{c}0.650 \dagger \\
(-2.569)^{* *}\end{array}$ \\
\hline $\ln M_{-1}$ & & $\begin{array}{c}-0.656 \\
(-4.055) * * *\end{array}$ \\
\hline $\ln Y_{-1}$ & & $\begin{array}{c}0.984 \\
(4.237)^{* * *}\end{array}$ \\
\hline $\ln \left(P_{-1} / P m_{-1}\right)$ & & $\begin{array}{c}0.521 \\
(3.229)^{* * *}\end{array}$ \\
\hline Constant & & $\begin{array}{c}-10.973 \\
(-4.401)^{* * * *}\end{array}$ \\
\hline$V C_{-1}$ & $\begin{array}{c}-0.386 \\
(-4.379) * * *\end{array}$ & \\
\hline
\end{tabular}

$\dagger$ Relative prices are expressed as $P m_{-1} / P_{-1}$

$V C_{-1} \rightarrow \ln M_{-1}+9.905-1.777 \ln Y_{-1}-1.669 \ln \left(P_{-1} / P m_{-1}\right)$

t-stats $\rightarrow$ 5.984***, $-10.929 * * *,-4.305^{* * *}$ 
Table 5. Price deflator. Dependent variable $\Delta \ln P$

\begin{tabular}{|c|c|c|}
\hline Coefficient of: & $\begin{array}{c}\text { Our estimates } \\
1978-2016\end{array}$ & $\begin{array}{c}\text { Onaran-Galanis } \\
1980-2007\end{array}$ \\
\hline$\Delta \ln P_{-1}$ & $\begin{array}{c}0.831 \\
(6.799)^{* * *}\end{array}$ & $\begin{array}{c}0.066 \\
(0.602)\end{array}$ \\
\hline$\Delta \ln P_{-2}$ & $\begin{array}{c}-0.226 \\
(-1.925)^{*}\end{array}$ & \\
\hline$\Delta \ln P_{M-1}$ & & $\begin{array}{c}0.03 \\
(0.831)\end{array}$ \\
\hline$\Delta \ln U L C_{-1}$ & $\begin{array}{c}0.256 \\
(4.226)^{* * *}\end{array}$ & $\begin{array}{c}0.771 \\
(7.480)^{* * *}\end{array}$ \\
\hline$r$ & $\begin{array}{c}-0.004 \\
(-4.200)^{* * *}\end{array}$ & \\
\hline Constant & & $\begin{array}{c}0.009 \\
(1.643)^{*}\end{array}$ \\
\hline$V C-1$ & $\begin{array}{r}-0.006 \\
(-1.947 *)\end{array}$ & \\
\hline
\end{tabular}

$r$ stands for the real interest rate

$V C_{-1} \quad \rightarrow \quad \ln P_{-1}+61.9-14.3 \ln P m_{-1}-2.005 \ln U L C_{-1}$

t-stats $\rightarrow \quad 1.855^{*},-2.085^{* * *},-1.840^{*}$ 
Table 6. Export price. Dependent variable $\Delta \ln P_{X}$

\begin{tabular}{|c|c|c|}
\hline Coefficient of: & $\begin{array}{c}\text { Our estimates } \\
1978-2016\end{array}$ & $\begin{array}{c}\text { Onaran-Galanis } \\
1980-2007\end{array}$ \\
\hline Constant & $\begin{array}{c}-0.039 \\
(-4.544) * * *\end{array}$ & $\begin{array}{c}-0.008 \\
(-0.773)\end{array}$ \\
\hline$\Delta \ln P_{X-1}$ & $\begin{array}{c}-0.316 \\
(-3.308) * * *\end{array}$ & \\
\hline$\Delta \ln P_{X-2}$ & $\begin{array}{c}-0.201 \\
(-2.323) * *\end{array}$ & \\
\hline$\Delta \ln P$ & $\begin{array}{c}0.419 \\
(2.811)^{* * *}\end{array}$ & \\
\hline$\Delta \ln P_{-1}$ & $\begin{array}{c}-0.339 \\
(-2.917) * * *\end{array}$ & \\
\hline$\Delta \ln P_{X^{*}}$ & $\begin{array}{c}0.277 \\
(5.296) * * *\end{array}$ & \\
\hline$\Delta \ln U L C$ & & $\begin{array}{c}0.322 \\
(2.234)^{* * * *}\end{array}$ \\
\hline$\Delta \ln P_{M}$ & & $\begin{array}{c}1.035 \\
(14.034)^{* * *}\end{array}$ \\
\hline$V C_{-1}$ & $\begin{array}{c}-0.717 \\
(-8.370) * * *\end{array}$ & \\
\hline
\end{tabular}

$V C_{-1} \quad \rightarrow \quad \ln P_{X-1}-0.107 \ln P_{-1}-0.931 \ln P_{X^{*}-1}$

t-stats $\rightarrow \quad-11.167 * * *,-84.251 * * *$ 
Table 7. Elasticities of $C, I$ and $M$ with respect to $Y$

\begin{tabular}{|c|c|c|c|}
\hline & $\begin{array}{c}\text { Our estimates } \\
1978-2016\end{array}$ & $\begin{array}{c}\text { Onaran-Galanis } \\
1980-2007\end{array}$ & $\begin{array}{c}\text { Molero-Simaro } \\
1978-2007\end{array}$ \\
\hline$e_{C Y}$ & 0.85 & 0.54 & 0.75 \\
\hline$e_{I Y}$ & 0.77 & 2.03 & 0.68 \\
\hline$-e_{M Y}$ & -1.43 & -1.50 & -0.23 \\
\hline$h_{1}$ & 0.33 & 0.19 & N/A \\
\hline Multiplier & 1.49 & 1.23 & N/A \\
\hline
\end{tabular}

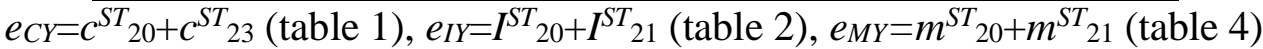

$h_{1}$ is the sum of $\partial C / \partial Y=e_{C Y}(C / Y), \partial I / \partial Y=e_{I Y}(I / Y)$ and $-\partial M / \partial Y=-e_{M Y}(M / Y)$ 
Table 8. Effects of a $1 \%$ increase in the labor share

\begin{tabular}{|c|c|c|c|}
\hline & $\begin{array}{c}\text { Our estimates } \\
1978-2016\end{array}$ & $\begin{array}{c}\text { Onaran-Galanis } \\
1980-2007\end{array}$ & $\begin{array}{c}\text { Molero-Simaro } \\
1978-2007\end{array}$ \\
\hline$C / Y$ & 0.63 & 0.41 & 0.29 \\
\hline I/Y & -0.24 & 0.00 & -0.22 \\
\hline Internal effects & 0.39 & 0.41 & 0.07 \\
\hline$N X / Y$ & -0.06 & -1.99 & -0.08 \\
\hline$h_{2}$ & 0.33 & -1.58 & -0.01 \\
\hline$d Y^{*} / d \Omega$ & 0.48 & -1.95 & N/A \\
\hline
\end{tabular}

Note: $h_{2}$ is the sum of marginal effects of $C / Y, I / Y$ and $N X / Y$.

The marginal effect of $N X / Y$ is calculated as $\partial(X / Y) / \partial(W / Y)-\partial(M / Y) / \partial(W / Y)$

$\partial(X / Y) / \partial(W / Y)=-\left(e_{U L C, R U L C}\right)\left(e_{P x, U L C}\right)\left(e_{X, P x}\right)\left(Y^{f} / Y\right)(X / Y) / R U L C$

$\partial(M / Y) / \partial(W / Y)=\left(e_{P, U L C}\right)\left(e_{U L C, R U L C}\right)\left(e_{M P}\right)\left(Y^{f} / Y\right)(M / Y) / R U L C^{20}$

${ }^{20}$ The ratio $Y^{f} / Y(=0.867)$ and the result whereby $e_{U L C, R U L C}=\partial \ln U L C / \partial \ln R U L C=1 /\left(1-\beta_{U L C}\right)$, where $\beta_{U L C}$ is the effect of unit labor costs on prices, are taken from Onaran and Galanis (2012). 